\title{
DISEMINASI INFORMASI PERTANAHAN MELALUI KELOMPOK MASYARAKAT DALAM PENSERTIPIKATAN TANAH DI KABUPATEN BANTUL
}

\author{
Dissemination of Land Information Through \\ Community Groups in Land Certification
}

\section{Oleh: Yoseph Nai Helly}

\begin{abstract}
Dissemination is an activity aimed at target groups or individuals so that they obtain information, there is awareness, acceptance, and ultimately use that information for their own interests. Dissemination of information is carried out by officers of Bantul District Land Office and community groups in the Banyudono, Sruwuh and Busuran hamlets in the effort to increase land certification.

In order the community to realize the importance and benefits and fuction of land certification, is necessary to disseminate appropriate information. Land through community groups in land certification. In Bantul regency, dissemination of information can be done through several ways, including: Counseling, Leaflets / Brochures, Announcements, Bantul Expo, Mass Media and Larasita. Larasita is a government program for rural areas/ villages to certify their land.

The government has tried to accelerate land certification programs through several programs, namely: Prona Program (Project of National Operational Land), LMPDP Program (Land Management Policy and Development Project), SMEs (Small and Medium Enterprises), Routine, P4T (Mastery Ownership and Use of Land Utilization), LC (Land Consolidation) self-help.

The research result shows that the dissemination of information conducted by government is running well with support from the community that the process of land certification in Bantul Regency can run smoothly and all rights of possessed land can be certificated. Hence, certificates of land right can be utilized by the community to increase their better economic life level, guarantee the law of land right legally according to the regulation, reduce conflict and quarrel of land which will arouse among people in the fut ure.
\end{abstract}

Keywords: Information Dissemination; Land Certificate

* Pustakawan.....

Mahasiswa S2 MIP Fakultas Ilmu Sosial dan Politik, Universitas Gajah Mada Yogyakarta

\section{A. Latar Belakang}

Bumi dan air dan kekayaan alam yang terkandung di dalamnya dikuasai oleh negara dan dipergunakan untuk sebesar-besar kemakmuran rakyat (UUD 1945 pasal 33 ayat 3). Dasar dari kebijakan pemerintah di bidang pertanahan yang tertinggi adalah undang-undang dasar 1945, yang sudah dirumuskan oleh para pejuang-pejuang bangsa Indonesia sejak jaman perjuangan untuk memperoleh kemerdekaan. Lahirnya UUPA bukanlah suatu proses yang pendek, melainkan sebuah proses yang panjang yaitu mulai dengan panitia agraria Yogyakarta (1948), panitia
Jakarta (1951), panitia Soewahjo (1956), Rancangan Soenario (1958), dan akhirnya rancangan Sadjarwo (1960). Dengan demikian para pejuang bangsa kita telah menyadari bahwa suatu program pembangunan terutama memihak rakyat banyak, perlu dilandasi lebih dahulu dengan penataan kembali masalah pertanahan, sebelum jauh menjangkau industrialisasi (Wiradi, 2001:11). Hal tersebut dilakukan untuk menjabarkan pelaksanaan UUD 1945 ke dalam sebuah undang-undang yaitu Undang-Undang Nomor 5 Tahun 1960 Tentang Peraturan Dasar Pokok - PokokAgraria, yang lebih khusus tentang 
pertanahan atau yang lebih dikenal dengan UUPA.

Tanah untuk sebesar-besar kemakmuran rakyat. Demi mencapai masyarakat yang makmur melalui kontribusi pertanahan, maka tanah perlu dikelola dengan baik sehingga akan mendatangkan kemakmuran bagi masyarakat. Tanah pada tingkatan tertinggi dikuasai oleh negara dan penggunaannya diatur untuk sebesarbesar kemakmuran rakyat (UUPA No.5/1960, pasal 2 ayat 3 ).

Agar terbukti tanah memberikan manfaat kesejahteraan bagi masyarakat maka tanah harus diproses pendaftaran haknya untuk selanjutnya diberikan sertipikat sebagai tanda bukti hak atas tanah yang kuat dan sah. Tujuan pendaftaran tanah untuk memberikan kepastian hukum dan perlindungan hukum kepada pemegang hak atas suatubidang tanah (PPNo.24/1997:3).

Namuñ di lain sisi, masyarakat masih beranggapan bahwa pelayanan di bidang pertanahan masih sangat sulit dan berbelit-belit dalam prosedur, lamanya waktu pemrosesan serta biaya yang sangat mahal. Penyebabnya bisa karena pelayanan Kantor Pertanahan yang kurang optimal. Hal ini menunjukkan adanya tuntutan masyarakat akan perlunya keterbukaan dalam pelaksanaan tugas, prosedur pembayaran yang sederhana, kepastian waktu dan besarnya biaya yang harus dibayar oleh masyarakat dalam penyelesaian urusan hak atas tanahnya, serta berbagai kemudahan dalam pelayanan maupun perlindungan hak-hak dan kepentingan masyarakat.

Banyak masyarakat yang belum mengetahui bagaimana proses ataupun informasi mengenai cara pensertipikatan tanah serta apa manfaatnya sertipikat bagi kehidupan masyarakat. Sedang dilihat dari sisi kebudayaan masyarakat merasa bahwa tidak akan ada yang merebut tanah miliknya, sebab semua masyarakat juga tahu bahwa tanah itu milik keluarganya secara turun termurun. Dalam tradisi atau sistem norma di Indonesia, kepastian akan status tanah tidak berdasarkan atas surat atau sertipikat, akan tetapi didasarkan oleh pengakuan komunitas.

Berdasarkan hal tersebut diatas maka masyarakat perlu diberikan informasi yang lengkap mengenai tata cara (proses), lamanya, persyaratan apa saja, berapa biayanya, jalur pensertipikatan tanah serta keuntungankeuntungannya.

\section{B. Rumusan Masalah}

Berdasarkan latar belakang dimaksud di atas maka dapat dirumuskan permasalahan penelitian sebagai berikut:

Bagaimana diseminasi informasi pertanahan melalui kelompok masyarakat dalam pensertipikatan tanah di kabupaten Bantul?

\section{Tinjauan Pustaka \\ Diseminasi Informasi}

Beberapa pakar maupun Undang-Undang, mendefinisikan informasi sebagai berikut: Menurut Undang-Undang Republik Indonesia Nomor 14 tahun 2008, berbunyi: Informasi adalah keterangan, pernyataan, gagasan, dan tanda-tanda yang mengandung nilai, makna, dan pesan, baik data, fakta maupun penjelasannya yang dapat dilihat, didengar, dan dibaca yang disajikan dalam berbagai kemasan dan format sesuai dengan perkembangan teknologi informasi dan komunikasi secara elektronik ataupun nonelektronik. Agar informasi mempunyai nilai yang berarti, maka data tersebut harus memenuhi syarat-syarat sebagai berikut:

a. Ketelitian atau kelengkapan data, pengambilan data harus dilakukan secara teliti. Misalnya tidak boleh adanya data yang tertinggal, dimana data tersebut harus terambil tetapi karena sesuatu hal maka data tersebut tidak terambil.

b. Waktu pengolahan data, apabila pengolahan data tersebut terlalu cepat atau terlalu lama, maka informasi yang akan dihasilkan tidak akan ada manfaatnya. 
c. Sumber data, salah penentuan sumber data, maka data yang terambil akan salah dan hal ini akan berpengaruh pada informasi

Informasi akan bermanfaat jika informási tersebut akurat, lengkap, relevan, tepat waktu, dapat diukur, dan harus dapat dibuktikan. Selanjutnya informasi diperlukan masyarakat setiap hari dalam komunitasnya untuk menjalankan aktifitas, terutama pada masyarakat demokratis saat ini. Demikian dikatakan Bryson, (1997:18), sebagai berikut: "Informasi diperlukan bagi orang-orang yang mengambil keputusan dalam masyarakat sehari-hari. Seperti di lingkungan perusahaan, bentuk pemberdayaan ini sangat berpengaruh. Ia juga merupakan ciri khas dari masyarakat demokratis".

Penyebaran informasi sebagai proses membuat informasi yang tersedia bagi publik. Pemerintah atau suatu badan yang berwenang, tidak hanya mengatur kualitas dan kuantitas informasi yang dapat menyebarluaskan kepada publik, tetapi juga harus sistematis disebarkan ke kelompok orang (http://www.blurtit.com/ q817753.html).

Perilaku yang dimiliki oleh suatu organisasi perlu didiseminasikan kepada kelompok yang lebih kecil atau masyarakat secara umum. Berkaitan dengan diseminasi informasi, dalam industri penerbitan terdapat konsep penyebaran (diseminasi). Ini berarti penyebaran informasi yang telah dimasukkan ke dalam bentuk material, dicetak di atas kertas, dan merupakan proses menerjemahkan informasi ke dalam bentuk materi yang menentukan sifat dari industri penerbitan itu sendiri (Feather, 1996:37).

\section{Kebijakan Pertanahan}

Kebijakan pemerintah tentang pertanahan selalu merubah mulai dari organisasinya maupun peraturan pelaksanaan yang lebih detail mengenai pertanahan. Dengan demikian masyarakat sebagai tujuan akhir dari sebuah pembangunan, memperoleh imbas yang kurang menguntungkan.
Salah satu kegiatan pertanahan kepada masyarakat adalah pendaftaran tanah yang menghasilkan produk pertanahan yang dapat memperkuat kepemilikan hak atas tanah pada masyarakat. Produk pertanahan tersebut adalah sertipikat hak atas tanah. Sertipikat merupakan bukti hak yang sah dan kuat secara hukum yang dijamin oleh pemerintah.

Pendaftaran tanah dilaksanakan berdasarkan azas sederhana, aman, terjangkau, mutakhir dan terbuka. Pendaftaran tanah bertujuan: a). Untuk memberikan kepastian hukum dan perlindungan hukum kepada pemegang hak atas suatu bidang tanah, satuan rumah susun dan hak-hak lain yang terdaftar agar dengan mudah dapat membuktikan dirinya sebagai pemegang hak yang bersangkutan. Untuk itu kepada pemegang hak atas tanah diberikan sertipikat sebagai surat tanda bukti hak atas tanah yang dijamin oleh Undang-Undang. Sertipikat merupakan surat tanda bukti hak yang berlaku sebagai alat pembuktian yang kuat mengenai data fisik dan data yuridis yang termuat di dalamnya, sepanjang data fisik dan data yuridis tersebut sesuai dengan data yang ada dalam surat ukur dan buku tanah hak yang bersangkutan (PP No.24/1997 pasal 32 ayat 1$)$.

Sumardjono, (2001:182), mengatakan sertipikat hak atas tanah sebagai hasil akhir proses pendaftaran tanah, berisi data fisik tentang letak, luas tanah, dan lain-lain; Data yuridis berisi status tanah, bangunan, pemilik tanah, dan hak pihak lain.

Sertipikat memberikan berbagai manfaat kepada masyarakat melalui pembangunan untuk mensejahterakan masyarakat. Misalnya dengan sertipikat nilai tanah menjadi meningkat, dengan sertipikat masyarakat dapat meminjam uang di bank untuk membuka usaha-usaha yang sesuai dengan yang dikehendakinya.

\section{Kelompok Sosial}

Kelompok adalah sekumpulan orang yang mempunyai tujuan bersama yang berinteraksi satu sama lain untuk mencapai tujuan bersama, 
mengenal satu sama lainnya, dan memandang mereka sebagai bagian dari kelompok tersebut (Mulyana, 2005). Kelompok ini misalnya adalah keluarga, kelompok diskusi, kelompok pemecahan masalah, atau suatu komite yang tengah berapat untuk mengambil suatu keputusan.

Kelompok sosial atau kelompok masyarakat merupakan kumpulan orang-orang yang mendiami suatu tempat dengan memiliki tujuan tertentu serta saling membutuhkan antara satu dengan yang lainnya.

Hubungan yang saling membutuhkan antar keluarga satu dengan yang lain bertujuan untuk saling membantu dalam menghadapi penyelesaian suatu masalah, baik itu disadari maupun tidak disadari setiap manusia ataupun kelompok akan menghadapi masalah, oleh karena itu membutuhkan orang lain.

Pembentukan kelompok masyarakat dapat dilakukan dengan tujuan untuk membangun kepercayaan masyarakat kepada suatu organisasi yang lebih besar seperti pemerintah maupun untuk melibatkan masyarakat berpartispasi dalam pelayanan pembangunan secara langsung, sehingga diharapkan membawa manfaat bagi kehidupan masyarakat itu sendiri. Untuk itu perlu melibatkan masyarakat dalam pelayanan pembangunan dengan membangun kepercayaan masyarakat dan pemberdayaan masyarakat.

\section{METODE PENELITIAN}

Cara penelitian ini menggunakan metode penelitian deskriptif dengan pendekatan kualitatif yang bermaksud untuk membuat pecandraan (deskripsi) mengenai situasi-situasi atau kejadian-kejadian yang terjadi pada tempat penelitian.

Metode penelitian yang digunakan untuk meneliti kondisi obyek yang alamiah, dimana peneliti berfungsi sebagai instrumen kunci, dalam pengumpulan data dilakukan secara trianggulasi (gabungan), analisis data bersifat induktif, dan hasil penelitian kualitatif lebih menekankan makna daripada generalisasi.

Data dikumpulkan baik berasal dari data primer maupun data sekunder dengan cara wawancara kepada informan yaitu Petugas Kantor Pertanahan dan Kelompok Masyarakat dengan cara melakukan wawancara dan pengamatan/observasi terhadap obyek penelitian

Data sekunder dalam penelitian ini berupa jumlah sertipikat yang telah dikerjakan oleh kantor pertanahan, peta per desa/kelurahan per kecamatan di kabupaten Bantul, luas wilayah administrasi serta jumlah bidang tanah yang ada di Kabupaten Bantul.

Wawancara merupakan teknik pengumpulan data untuk memperoleh informasi secara langsung melalui permintaan keteranganketerangan kepada pihak pertama yang dipandang dapat memberikan keterangan atau jawaban terhadap pertanyaan yang diajukan. Informan dalam penelitian ini terdiri dari petugas Kantor Badan Pertanahan Nasional Kabupaten Bantul dan Kelompok Masyarakat Pedukuhan Banyudono, Desa Canden, Kecamatan Jetis serta Kelompok Masyarakat Sruwuh dan Busuran Desa Donotirto, Kecamatan Kretek. Peneliti mengajukan pertanyaan secara terbuka dan langsung dijawab secara bebas oleh informan sesuai dengan yang diharapkan.

Populasi dalam penelitian ini adalah semua kelompok masyarakat yang terlibat dalam kegiatan pensertipikatan tanah baik yang dilaksanakan melalui program pemerintah berupa proyek operasional nasional agraria (PRONA) maupun land management policy and development project (LMPDP) di Kabupaten Bantul pada tahun 2009, juga aparat (pegawai) Kantor Pertanahan Kabupaten Bantul yang menjadi pelaksana kegiatan program pemerintah tersebut dalam rangka pensertipikatan tanah di Kabupaten Bantul.

Dalam penelitian ini, peneliti mengambil beberapa kelompok masyarakat yang mewakili semua populasi pensertipikatan tanah di kabupaten Bantul melalui program LMPDP dan 
PRONA. Kelompok masyarakat yang mewakili program LMPDP adalah kelompok masyarakat yang ada di desa Canden yaitu dusun Banyridono Kecamatan Jetis. Sedangkan kelompok masyarakat yang mewakili program PRONA adalah kelompok masyarakat pedukuhan Sruwuh dan pedukuhan Busuran Desa Donotirto Kecamatan Kretek.

Data yang telah dikumpulkan dilakukan analisis dengan menggunakan metode deskriptif kualitatif, yakni analisis data dengan menyeleksi dan memilih data yang menggambarkan sebenarnya di lapangan sesuai dengan kualitas dan kebenarannya. Data dimaksud kemudian dihubungkan dengan teori-teori yang diperoleh dari studi kepustakaan dan dokumen.

Data primer yang berupa angka disajikan dalam bentuk tabel agar memudahkan deskripsi serta analisisnya. Data sekunder yang diperoleh dari penelitian kepustakaan dijadikan pedoman dalam melakukan analisis.

\section{E. Hasil Penelitian}

\section{Pensertipikatan Tanah}

Jumlah bidang tanah di Kabupaten Bantul adalah 566.451 bidang. Bidang tanah yang sudah bersertipikat sampai dengan tanggal 24 Agustus 2009 adalah 398.577 bidang ( $\pm 70 \%$ ), dan masih kurang $167.874( \pm 30 \%)$ bidang tanah yang belum disertipikatkan.

Wilayah yang dekat dengan perkotaan seperti Kecamatan Kasihan jumlah sertipikat sangat banyak, artinya kesadaran masyarakat akan pentingnya surat tanda bukti hak atas tanah berupa sertipikat sangat penting untuk dimiliki. Sedangkan wilayah yang agak jauh dari perkotaan minat masyarakat untuk mensertipikatkan tanahnya sangat minim.

\section{Upaya Peningkatan Pensertipikatan Tanah}

Pemerintah melalui Badan Pertanahan Nasional memprogramkan agar semua bidang tanah terdaftar dan memiliki surat tanda bukti hak berupa sertipikat hak atas tanah, untuk itu Badan Pertanahan Nasional telah berusaha untuk menyebarkan informasi yang sebanyakbanyaknya tentang pertanahan termasuk pemeliharaan surat tanda bukti hak (sertipikat) yang telah dimiliki.

Upaya yang dilakukan oleh Badan Pertanahan Nasional Republik Indonesia kepada kantor pertanahan kabupaten Bantul dalam pensertipikatan tanah pada tahun 2009 adalah 5000 bidang melalaui program Prona; 15.000 bidang tanah melalui program LMPDP; P4T; Pertanian 500 bidang; UMKM sebanyak 100 bidang; dan LC Massal swadaya sebanyak 5000 bidang; dan Rutin berjumlah 600 bidang/bulan atau (7200/tahun). Dengan demikian target pensertipikatan tanah di kabupaten Bantul pada tahun 2009 adalah 32.800 bidang. Jika ditargetkan setiap tahun 32.800 bidang tanah di kabupaten Bantul disertipikatkan maka membutuhkan waktu \pm 7 tahun lagi. Artinya pada tahun 2016 semua bidang tanah di kabupaten Bantul sudah selesai disertipikatkan. Dengan demikian tidak membutuhkan waktu yang terlalu lama dalam mensertipikatkan tanah, seperti apa yang dikatakan oleh Kepala BPN Joyo Winoto pada acara penyerahan sertipikat hak atas tanah di Wonosari. Joyo Winoto mengatakan bahwa untuk menyelesaikan pensertipikatan hak atas tanah di seluruh Indonesia dibutuhkan waktu kurang lebih 120 tahun atau 4 generasi. Namun menurut Kepala BPN RI waktu tersebut dinilai terlalu lama, sehingga perlu diambil kebijakan dan terobosan-terobosan, sehingga dengan adanya Reformasi Agraria, tanah yang belum bersertipikat bisa diselesaikan dalam waktu 18 tahun. Bahkan kurun waktu tersebut masih bisa dipercepat lagi, dengan meningkatkan pelayanan.

\section{Sistem Loket}

Sistem loket yang ada pada kantor pertanahan dalam rangka pelayanan pertanahan kepada masyarakat terdiri dari 4 (empat) loket. Loket I adalah loket informasi; Loket II adalah pemeriksaan berkas; Loket III pembayaran 
administrasi; Loket IV adalah pengambilan hasil produk.

Loket I mengenai pelayanan informasi yang semestinya berisi berbagai informasi tentang pelayanan pertanahan kepada masyarakat secara umum, detail dan lengkap sehingga masyarakat mendapatkan kejelasan. McFaden, dkk 1999 (dalam Kadir, 2002: 31) mendefinisikan informasi sebagai data yang telah diproses sedemikian rupa sehingga meningkatkan pengetahuan seseorang yang menggunakan data tersebut. Namun kenyataannya di kantor pertanahan hanya menyediakan informasi mengenai cara atau persyaratan yang harus dipenuhi dalam rangka mengajukan suatu proses hak secara umum.

Sedang jika masyarakat ingin mengetahui informasi lebih detail akan diarahkan kepada bagian/seksi tertentu yang menangani bidangnya secara khusus. Loket informasi hanya memberikan informasi secara umum tentang bagaimana mengurus sertipikat tanah, masalah, sengketa, proses pekerjaan sampai dimana, dll.

Dengan demikian bila masyarakat ingin mendapatkan informasi yang lebih detail harus menemui pejabat di bagian back office, setelah itu diarahkan kepada petugas khusus yang menangani informasi tersebut. Suatu contoh, ketika masyarakat ingin mengetahui jumlah sertipikat yang diproduksi kantor pertanahan suatu periode tertentu, tidak dengan cepat memperolehnya.

\section{Pembentukan Kelompok Masyarakat}

Kelompok masyarakat dibentuk oleh kelurahan/desa atas kerjasama dan masukan dari Badan Pertanahan Nasional Republik Indonesia Kabupaten Bantul dalam rangka pelaksanaan kegiatan pensertipikatan tanah kepada masyarakat. Kelompok masyarakat dibentuk atau ditunjuk oleh kelurahan (Kepala lurah/kepala desa) dengan dikoordinir oleh kepala pedukuhan untuk membantu petugas pertanahan dan masyarakat dalam kegiatan pensertipikatan tanah pada wilayah yang terkena program pemerintah di bidang pertanahan.

\section{Tujuan Pembentukan Kelompok Masyarakat}

Tujuan pembentukan kelompok masyarakat ini adalah untuk membantu aparat pertanahan dalam menjalankan kegiatan pensertipikatan tanah, juga membantu masyarakat setempat dalam hal diseminasi informasi maupun kegiatan langsung. Kelompok masyarakat ini diharapkan untuk membantu kegiatan pensertipikatan tanah kepada masyarakat yang dilakukan oleh aparat Badan Pertanahan Kabupaten Bantul sehingga dapat berjalan dengan baik dan lancar.

Yang menjadi motivasi kelompok masyarakat adalah sebagai bentuk tanggung jawab (kesanggupan) untuk melayani masyarakat, menambah pengetahuan lebih detail mengenai pertanahan, memiliki sertifikat. Di lain sisi informan di pedukuhan Banyudono mengatakan bahwa program ini prosesnya cepat dan murah. Sebab masyarakat mendapat informasi dari beberapa masyarakat yang sudah mengurus sendiri yang mengatakan bahwa mengurus sertipikat itu sangat sulit, mahal, dan lama.

\section{Struktur Kelompok Masyarakat}

Struktur kelompok masyarakat adalah sebagai berikut: Kepala dukuh sebagai koordinator serta anggotanya adalah para rukun tetangga (RT) serta masyarakat yang dianggap memiliki kemampuan oleh pimpinan pedukuhan dalam suatu pedukuhan untuk membantu kelancaran pekerjaan tersebut. Jumlah anggot dalam satu kelompok adalah enam sampai tujuh orang, serta tergantung jumlah RT-nya dalam suatu pedukuhan. Untuk lebih jelas lihat gambar berikut: 
Gambar 3.

Struktur Kelompok Masyarakat

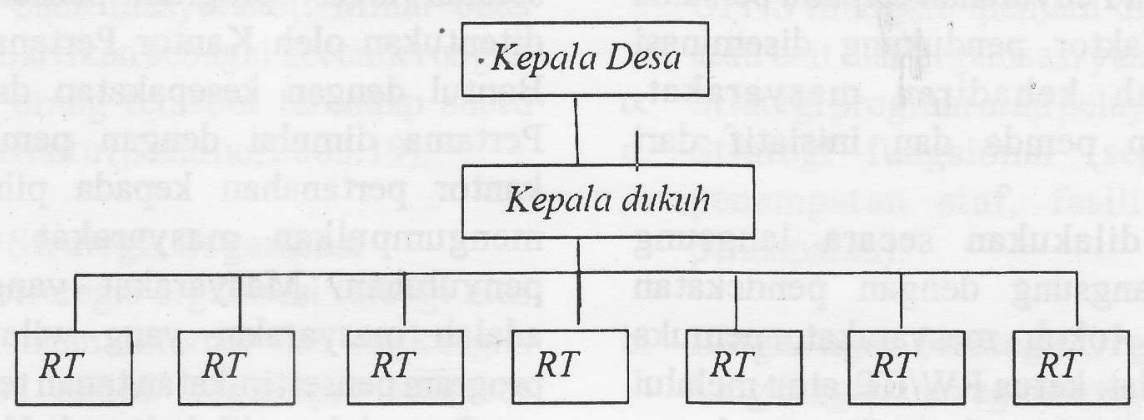

\section{Tugas Kelompok Masyarakat}

Tugas kelompok masyarakat dalam diseminasi informasi pertanahan secara khusus adalah:

a. Membantu Tim koordinasi untuk memperlancar dan mensukseskan pelaksanaan kegiatan

b. Mengadakan penyuluhan kepada masyarakat

c. Mengevaluasi dan mengarahkan kegiatan

d. Musyawarah dengan peserta

e. Lain-lain yang dianggap

Tugas yang dilakukan kelompok masyarakat meliputi dua bagian. Bagian pertama adalah tugas non lapangan yaitu mengumpulkan masyarakat untuk mengikuti penyuluhan; mengisi blanko permohonan: konversi, warisan, jual beli, hibah; bersama satgas yuridis melaksanakan pendataan / identifikasi peserta proyek/pemohon; mengumpulkan kelengkapan administrasi berupa KTP, KK, SPPT Pajak, alas hak berupa letter $C$, surat kematian. Bagian kedua adalah tugas lapangan yaitu penetapan batas/pemasangan patok dan pemeliharaan tanda batas bersama pemilik tanah; menunjukkan tanda batas dan pemilik tanah pada saat pengukuran; membantu menyelesaikan sengketa antara masyarakat.

\section{Cara Diseminasi Informasi}

Cara yang digunakan dalam diseminasi informasi pertanahan melalui kelompok masyarakat dalam pensertipikatan tanah melalui program-program pemerintah, seperti Program Nasional Pertanahan/Agraria (PRONA) maupun program LMPDP serta program lain. Cara-cara dimaksud adalah Penyuluhan, Leaflet/brosur, Papan pengumuman, Media massa, Bantul Expo dan Larasita. Untuk itu dapat dibahas sebagai berikut:

\section{a. Penyuluhan}

Penyuluhan sebagaimana dimaksud pada ayat (1) pasal 56 Peraturan Menteri Agraria/Kepala Badan Pertanahan Nasional Nomor 3 tahun 1997, bertujuan memberitahukan kepada pemegang atau kuasanya atau pihak lain yang berkepentingan bahwa di desa/kelurahan tersebut akan diselenggarakan pendaftaran tanah secara sistematik dan tujuan serta manfaat yang akan diperoleh dari hasil pendaftaran tanah tersebut.

Maksud dan tujuan penyuluhan agar masyarakat mengerti dan memahami maksud, tujuan, sasaran, manfaat, keuntungan tahapan kegiatan pensertipikatan tanah serta hak dan kewajibannya dengan tujuan agar mereka berperan aktif dalam pelaksanaan program pensertipikatan tanah.

Sebelum dimulainya kegiatan program pemerintah dalam pensertipikat an tanah, terlebih dahulu diadakan penyuluhan di wilayah atau bagian wilayah desa/kelurahan yang bersangkutan mengenai pendaftaran tanah secara sistematik oleh Kepala Kantor Pertanahan dibantu oleh stafnya serta instansi lain yang berkepentingan.

Yang melaksanakan penyuluhan adalah Kepala seksi pengendalian dan pemberdayaan masyarakat; Kepala sub seksi Pengendalian dan kepala subseksi pemberdayaan; Kepala seksi Hak 
Tanah dan Pendaftran Tanah berserta staf yang berkompeten; serta Penyuluhan terpadu bersama aparat pemda. Faktor pendukung diseminasi informasi adalah kehadiran masyarakat, kerjasama dengan pemda dan inisiatif dari masyarakat

Penyuluhan dilakukan secara langsung maupun tidak langsung dengan pendekatan informal melalui tokoh masyarakat, pemuka agama, pemuka adat, ketua RW/RT, atau melalui media massa baik cetak, audio/audio visual atau melalui pamflet, poster, spanduk, atau media lain yang dianggap efektif.

Penyuluhan dilakukan dengan sasaran masyarakat pemilik tanah atau yang menguasai tanah negara/tanah pemerintah/pemerintah daerah/BUMN/ BUMD sebagai calon peserta program pensertipikatan tanah, tokoh masyarakat, pemuka agama, pemuka adat, serta para pihak terkait pada lokasi terpilih.

Kelompok masyarakat yang menjadi sasaran penyuluhan dari pedukuhan; Jumlah peserta yang diminta adalah kurang lebih lima belas sampai dua puluh orang (15-20) orang. Isi penyuluhan ditujukan terutama kepada masyarakat yang ekonomi lemah mengenai manfaat dan pentingnya sertipikat, prosedur, biaya serta waktu, yang dilaksanakan dengan mudah dan murah.

Penyuluhan dari Badan Pertanahan Nasional hanya ada jika mau ada program pemerintah mengenai pensertitipikatan secara sistematis, selain itu tidak pernah ada secara khusus dan rutin. Tetapi setiap enam bulan ada penyuluhan terpadu dari instansi terkait dari pemda tingkat II kabupaten Bantul di kantor kecamatan.

Setelah memperoleh informasi melalui penyuluhan, kelompok masyarakat ini harus menyebarkan informasi tersebut kepada setiap warga secara perorangan yang telah dipilih menjadi obyek pensertipikatan tanah.

Jatah bidang tanah yang diberikan oleh Badan Pertanahan Nasional adalah 128 bidang untuk masing-masing pedukuhan dalam satu kelurahan/desa (di desa Donotirto).
Jadi proses penyuluhan dapat dilakukan setelah lokasi program pensertipikatan tanah ditentukan oleh Kantor Pertanahan Kabupaten Bantul dengan kesepakatan dari aparat desa. Pertama dimulai dengan pemberitahuan dari kantor pertanahan kepada pihak desa untuk mengumpulkan masyarakat agar diberikan penyuluhan. Masyarakat yang dikumpulkan adalah masyarakat yang wilayahnya terkena program pensertipikatan tanah tersebut.

Penyuluhan dilakukan di Kantor Desa satu kali sebelum program tersebut dilaksanakan. Isi penyuluhan tersebut meliputi persyaratanpersyaratan pemohon yang harus disiapkan serta selanjutnya dikumpulkan berupa, identitas pemohon serta blanko-blanko yang harus diisi oleh pemohon. Setelah itu penyuluhan masih dilaksanakan lagi di pedukuhan oleh kepala dukuh beserta kelompok masyarakat maupun satgas dari Kantor Pertanahan, juga pendamping kepada masyarakat secara terus-menerus sepanjang diperlukan.

\section{b. Leaflet/Brosur}

Membuat/menyediakan leaflet/brosur yang berisi mengenai informasi pertanahan yang dapat diakses atau dipelajari dan dilaksanakan oleh masyarakat yang ingin mengetahui proses pelayanan pertanahan. Leaflet/brosur dapat diperoleh di kantor pertanahan Kabupaten Bantul pada loket informasi atau pada Bantul Expo yang tersedia di stand Kantor Pertanahan Kabupaten Bantul pada saat Bantul Expo berlangsung di Bantul.

Leaflet/brosur dicetak secukupnya sesuai dengan kebutuhan saja, mengingat biaya yang agak mahal. Leaflet/brosur dapat dibagikan kepada masyarakat terutama kepada aparat desa/kelurahan secara umum yang selanjutnya didiseminasikan kepada masyarakat secara perorangan.

Semua desa di Kabupaten Bantul sudah diberikan leaflet/brosur untuk selanjutnya didiseminasikan kepada masyarakat oleh aparat desa. Misalnya dapat ditempelkan pada papan 
pengumuman di pedukuhan, RT, ataupun kampung-kampung sehingga dapat diketahui oleh anggota masyarakat secara umum.

\section{c. Papan Pengumuman}

Pengumuman bertujuan untuk memberi kesempatan bagi yang berkepentingan mengajukan keberatan mengenai data fisik dan data yuridis yang sudah dikumpulkan oleh petugas pengumpul data di lapangan. Pengumuman ini bermaksud agar semua informasi diketahui oleh masyarakat secara luas dan transparan, apabila ada masyarakat yang berkeberatan maka diperbolehkan untuk mengajukan gugatan.

Papan pengumuman yang tersedia dalam rangka diseminasi informasi pertanahan ditempatkan di Kantor Pertanahan Kabupaten Bantul dan di Kantor Desa/Kelurahan yang berhubungan langsung dengan pelaksanaan kegiatan pensertipikatan tanah di lokasi yang telah disepakati bersama antara Kantor Pertanahan Kabupaten Bantul dan Kelurahan/Desa

\section{d. Media Massa}

Media massa merupakan salah satu bentuk diseminasi informasi pertanahan, baik berupa media cetak maupun media elektronik. Media cetak biasanya dapat dimuat di surat kabar berupa koran-koran dan majalah-majalah. Media cetak dapat dimanfaatkan oleh Kantor Pertanahan Kabupaten Bantul pada saat ada event berupa penyerahan sertipikat ataupun event lain yang berkaitan dengan kegiatan pertanahan di Bantul.

Media elektronik dapat dilakukan oleh Kantor Pertanahan Kabupaten Bantul adalah melalui radio yang digagas oleh Pemerintah Daerah Kabupaten Bantul bekerjasama dengan perusahaan penyiaran radio Bantul FM. Kantor Pertanahan Kabupaten Bantul melakukan penyiaran melalui radio Bantul FM satu kali setiap bulan secara rutin. Informasi yang disiarkan berkaitan dengan pemahaman dan pengetahuan masyarakat tentang pertanahan baik secara umum maupun secara khusus.

\section{e. Bantul Expo}

Diseminasi informasi pertanahan dapat juga dilakukan melalui Bantul Expo yang diadakan setiap tahun. Bantul Expo dilaksanakan selama satu minggu di Bantul. Kantor Pertanahan memiliki stand sendiri dalam kegiatan tersebut.

Kantor Pertanahan melayani masyarakat melalui informasi berupa pertanyaan maupun brosur persyaratan pengurusan pensertipikatan tanah. Informasi yang paling banyak dibutuhkan oleh masyarakat adalah informasi berupa pertanyaan mengenai jual beli dan warisan.

\section{f. Larasita}

Layanan Rakyat untuk Sertipikasi Tanah atau yang disingkat dengan Larasita merupakan layanan masyarakat yang diberikan oleh pemerintah melalui Badan Pertanahan Nasional (BPN) kepada masyarakat. Layanan ini mulai dilaksanakan di Kantor Pertanahan Kabupaten Karang Anyar, Provinsi Jawa Tengah pada tahun 2006, dan lebih lanjut dilaksanakan di 13 Kabupaten/Kota pada tahun 2007, baik di Jawa maupun luar Jawa dengan tujuan untuk memudahkan pelayanan pertanahan dan sertipikasi tanah pada masyarakat.

Program Larasita dijalankan oleh satuan tugas Kantor Pertanahan setempat, dengan menggunakan kendaraan bermotor baik roda dua maupun roda empat untuk melaksanakan pelayanan pertanahan kepada masyarakat dalam wilayah administratif Kantor Pertanahan Kabupaten/Kota, secara online dengan pemanfaatkan teknologi mutakhir di bidang pendaftaran tanah, dengan Information Tecnology yang dihubungkan melalui satelit dengan memanfaatkan fasilitas internet dan "wireless commmunication system".

Larasita merupakan program nasional dan sepenuhnya menggunakan APBN Badan Pertanahan Nasonal Republik Indonesia. Meski sepenuhnya program nasional, program ini telah 
memperoleh pengakuan Bank Dunia dalam memberikan akses masyarakat, terutama masyarakat pedesaan yang jauh dari kota terhadap informasi dan pelayanan pertanahan.

Salah satu upaya menyadarkan masyarakat agar bersedia mensertifikatkan tanahnya adalah dengan menggalakkan program layanan rakyat untuk sertifikasi tanah (Larasita) di daerahdaerah pinggiran Kabupaten Bantul. Program Larasita, sejauh ini hasilnya cukup efektif. Dari 13.223 bidang tanah di Bantul yang disertifikasi pada periode Januari hingga Juli 2009, sebagian besar berada di daerah pinggiran. Daerah-daerah tersebut adalah Kecamatan Dlingo, dengan tanah yang belum bersertifikat mencapai 75,69 persen, kemudian Kecamatan Imogiri 70,61 persen, Piyungan 62 persen, Kretek 52,18 persen, dan di Kecamatan Sanden tanah belum bersertifikat mencapai 51 persen.

Menurut Kepala Kantor Pertanahan Kabupaten Bantul yaitu Ir. Mulyoko mengatakan bahwa, rendahnya kesadaran masyarakat untuk mengurus sertifikat tanah miliknya karena mereka beranggapan biasanya pengurusan sertifikat tanah membutuhkan waktu yang sangat lama, dan berliku-liku.

\section{g. Biaya Penyuluhan}

Biaya yang harus dikeluarkan oleh masyarakat dalam program PRONA pensertipikatan tanah maupun programa LMPDP adalah masing-masing seperti tertera dalam tabel berikut:

\section{Tabel}

Biaya pensertipikatan tanah melalui Prona dan LMPDP

$\begin{array}{llll}\text { No. Jenis Kegiatan } & \begin{array}{c}\text { PRONA } \\ \text { (Rp) }\end{array} & \begin{array}{c}\text { LMPDP } \\ \text { (Rp) }\end{array} \\ \text { 1. Konversi } & 150.000 & 150.000 \\ \text { 2. } & \text { Jual Beli } & - & 375.000 \\ \text { 3. } & \text { Hibah } & - & 375.000 \\ \text { 4. } & \text { Warisan } & 165.000 & 200.000 \\ \text { 5. } & \text { Model Gondok } & - & 150.000 \\ \text { 6. } & \text { Wakaf } & \text { Gratis } & \text { Gratis }\end{array}$

Biaya untuk proses kegiatan program ini gratis oleh pemerintah dalam hal ini Badan Pertanahan Nasional Republik Indonesia, namun oleh Kelurahan dengan disetujui DPRnya kelurahan/desa menarik biaya pendukung dari masyarakat sebesar seperti tertera dalam tabel 3 diatas dengan tujuan untuk administrasi, foto kopi, meterai dan pilar/patok (dibebankan kepada masyarakat).

\section{Keuntungan dan Hambatan Diseminasi Informasi}

a. Badan Pertanahan Nasional:

1. Keuntungan:

a. Masyarakat semakin mengetahui dan memahami informasi pertanahan

b. Menghilangkan image negatif tentang pelayanan pertanahan

c. Menghemat tenaga

d. Menghemat waktu

e. Memudahkan pelayanan kepada masyarakat ketika pelaksanaan kegiatan

2. Hambatan:

a. Masih kurangnya sumber daya manusia baik secara kuantitas maupun kualitas untuk melaksanakan pelayanan informasi pertanahan

b. Alokasi biaya yang dibutuhkan sangat besar

c. Keterbatasan waktu

d. Banyaknya pekerjaan rutin kantor yang harus diselesaikan

e. Kelompok masyarakat minta untuk bekerja pada malam hari

f. Pembentukan kelompok masyarakat oleh Badan Pertanahan Nasional akan menimbulkan konflik antara kelompok masyarakat dengan aparat kelurahan/desa

b. Kelompok Masyarakat:

1. Keuntungan:

a. Kekuatan hukum yang sah 
b. Dapat dijadikan agunan ke bank untuk usaha

c. Kenyamanan dan keamanan

d. Mengurangi sengketa dan konflik

e. Mudah dan murah

f. Waktu lebih efisien

2. Hambatan:

a. Sulit untuk melengkapi serta menyerahkan persyaratannya

b. Masyarakat tinggal di luar desa sehingga sulit dihubungi

c. Masyarakat berubah pikiran tentang bidang/pembagian yang telah dilakukan

d. Kelompok masyarakat sangat bekerja keras untuk menjembatani masyarakat

e. Masyarakat menganggap pemutihan sehinggga pasif dan tidak mau melengkapi semua persyaratan.

Masyarakat masih awam dan kurangnya informasi pertanahan secara rutin dari kantor pertanahan serta masih banyaknya masyarakat yang belum secara cepat dalam pengurusan pensertipikatan tanah.

Hambatan lain yakni: sepanjang pengamatan peneliti, di kantor pertanahan kabupaten Bantul, yang terlihat dalam pengurusan sertipikat adalah PPAT/Notaris. Peneliti bertanya dalam hati apa yang terjadi dengan masyarakat di Bantul sehingga tidak mau mengurus sertipikat tanah sendiri?

Ternyata masyarakat yang sebagai informan juga mengatakan bahwa:

a. Masyarakat tidak mau mengurus sertipikat sendiri ke kantor pertanahan karena aparat BPN kurang sopan dan santun, masih dipersulit, berbelit-belit, dan mahal

b. Masyarakat lebih baik menggunakan perantara yaitu PPAT/ Notaris, aparat desa/kelurahan, perantara lain yang paham tentang pertanahan

b. Konsekuensinya memang pengurusan sertipikat lebih mahal tetapi masyarakat tidak ingin mondar mandir tanpa kepastian/kejelasan di kantor pertanahan

c. Program Badan Pertanahan Nasional baru pada tahap pensertipikatan saja secara kuantitatif tetapi belum sampai pada bagaimana menjaga dan merawat tanah serta sertipikat yang telah dimiliki untuk tidak diberikan atau dipinjamkan kepada pihak lain sehingga salah dimanfaatkan atau dijual dengan harga murah.

d. Sumber daya manusia dan Anggaran

e. Sumber daya manusia yang tersedia pada Kantor Pertanahan Kabupaten Bantul masih sangat terbatas. Buktinya pada seksi pengendalian dan pemberdayaan masyarakat hanya terdapat lima orang pegawai dengan status sebagai berikut: kepala seksi satu orang, dua orang kepala sub seksi dan dua orang staf. It upun staf yang hampir pensiun.

f. Anggaran yang disediakan juga sangat terbatas, sehingga dengan demikian kurang mendukung kegiatan-kegiatan pertanahan yang patut diberikan kepada masyarakat

\section{E. Kesimpulan dan Saran}

1. Kesimpulan

Diseminasi informasi pertanahan melalui kelompok masyarakat dalam pensertipikatan tanah di Kabupaten Bantul dapat dijalankan melalui beberapa cara, antara lain penyuluhan, leaflet/brosur, papan pengumuman, media massa, Bantul Expo, dan Larasita. Cara-cara dimaksud dapat berjalan dengan baik dan lancar serta membawa manfaat positif kepada masyarakat pemilik tanah terutama bagi masyarakat yang terlibat ataupun dilibatkan dalam kegiatan program tersebut.

Diseminasi informasi pertanahan melalui kelompok masyarakat dalam pensertipikatan tanah di Kabupaten Bantul berawal dari upaya pemerintah untuk meningkatkan pensertipikatan atas bidang-bidang tanah dalam waktu yang lebih cepat.

Implikasi sertifikasi tanah yang telah dilakukan oleh pemerintah di Kabupaten Bantul mengalami peningkatan yang signifikan baik 
secara kuantitas maupun kualitas pelayanannya, baik yang ada di perkotaan maupun di pedesaan. Dengan demikian upaya yang telah dilakukan membawa manfaat positif kepada masyarakat. Masyarakat merasa aman karena telah memiliki sertipikat hak atas bidang tanahnya sebagai tanda bukti hak yang sah dan kuat secara hukum serta mengurangi terjadinya konflik pertanahan diantara mereka.

\section{Saran}

Bertolak dari kelemahan-kelemahan yang terjadi dalam pensertifikatan dan dalam proses diseminasi informasi pertanahan, maka dapat kami sarankan sebagai berikut :

a. Loket (I) Informasi

Diseminasi informasi pertanahan di Kantor Pertanahan Kabupaten Bantul akan sangat baik, jika informasi yang dikemas, diorganisir dengan baik sehingga menyediakan data-data yang lengkap, detail, pasti dan jelas pada loket I, sehingga dapat menjawab kebutuhan masyarakat tanpa harus ke bagian belakang pelayanan informasi atau malah membingungkan masyarakat. Pelayanan informasi juga harus memperhatikan etika dan estetika yang baik.

b. KelompokMasyarakat

Kantor Pertanahan Kabupaten Bantul hendaknya bekerjasama dengan pemerintahan Desa untuk membentuk kelompok masyarakat pertanahan yang bekerja untuk mendiseminasikan informasi pertanahan kepada masyarakat umum pada setiap wilayahnya secara terus menerus tanpa dibatasi waktu atau ruang.

\section{DAFTAR REFERENSI}

1. Buku:

Bryson, Jo. 1997. Managing Information Services An Integrated Approach. England: Gower

Dwiyanto, Agus. 2002. Reformasi Birokrasi Publik di Indonesia. Yogyakarta: Pusat Studi Kependudukan dan Kebijakan UGM

Feather, John. 1996. The Information Society A study of continuity and change. London: Library Association Publishing.

Kadir, Abdul. 2002. Pengenalan Sistem Informasi: Yogyakarta: Andi

Mulyana, Deddy. 2005. Ilmu Komunikasi. Suatu Pengantar. Bandung: Remaja Rosdakarya.

Sumardjono, Maria. S.W. 2001. Kebijakan pertanahan antara regulasi \& Implementasi. Jakarta: Kompas

2. Dokumen:

Peraturan Presiden Nomor 10 Tahun 2006 Tentang Badan Pertanahan Nasional

Peraturan Pemerintah Republik Indonesia Nomor 24 Tahun 1997 Tentang Pendaftaran Tanah

Peraturan Menteri Negara Agraria/Kepala Badan Pertanahan Nasional Nomor 3 Tahun 1997 Tentang Ketentuan Pelaksanaan Peraturan Pemerintah Nomor 24 Tahun 1997 (Pendaftaran Tanah)

3. Internet:

http://www.blurtit.com/q817753.htm1 (Rabu, 3-3-2010) 